\title{
Clinical Dosimetric Comparison of Three Radiotherapy Techniques for Left-Sided Breast and Lymphatic Irradiation
}

\section{Sol Meme ve Lenfatik Ișınlamada Üç Farklı Radyoterapi Tekniğinin Klinik Dozimetrik Karșılaștırılması}

\author{
(1) Elif Eda Özer, (1) Gülșen Pınar Soydemir, (1) Meltem Kırlı, (1) Gülșah Özkan \\ University of Health Sciences Turkey, Bakırköy Dr. Sadi Konuk Training and Research Hospital, Clinic of Radiation Oncology, İstanbul, Turkey
}

\begin{abstract}
Objective: We compared the dosimetric differences between three treatment modalities, including three-dimensional conformal radiation therapy (3D-CRT), intensity-modulated radiotherapy (IMRT), and volumetric intensity-modulated arc therapy (VMAT) planning methods, for the breast tangential field and lymphatic draining region following breast radiotherapy in ten patients with left-sided breast carcinoma.

Method: For each patient undergoing breast-conserving surgery and dissection of selected axillary lymph nodes, 3D-CRT, IMRT, and VMAT were planned. Dosimetric parameters of target volumes and organs at risk (OAR) were compared. Planned target volume (PTV) was the whole breast and lymphatic region. A total of 50 Gy was administered at the rate of 2 Gy/fraction to all patients.

Results: The dose received by $2 \%$ of the PTV for breast radiotherapy was lowest in IMRT planning ( $p=0.001)$; the dose for supraclavicular region was lowest in VMAT ( $p=0.001$ ). The dose received by $95 \%$ and $98 \%$ of the PTV for the axillary region was lowest in 3D-CRT ( $p=0.002$ and 0.045 , respectively). The doses of OAR, including the heart, ipsilateral and contralateral lung, and contralateral breast were lowest in 3D-CRT planning $(p<0.01)$. IMRT showed the lowest monitor units $(p=0.001)$.

Conclusion: All three planning methods met the dosimetric criteria in patients with breast and axilla radiotherapy indications after breast-conserving surgery. Although each treatment technique has its own advantages and disadvantages, 3D-conformal plans may provide a lower dose coverage for the 0AR, which is important for long-term side effects and secondary cancer development.
\end{abstract}

Keywords: 3D conformal treatment, intensity-adjusted radiotherapy, volumetric intensity-modulated arc therapy, breast cancer

\section{ÖZ}

Amaç: Üç farklı tedavi yöntemi arasındaki dozimetrik farklııkları karșılaştırmayı amaçladık. Sol meme kanseri olan 10 hastada meme tanjensiyel alan ve lenfatik drenaj bölgesi için üç boyutlu konformal radyoterapi (3D-CRT), yoğunluk ayarlı radyoterapi (IMRT) ve hacimsel yoğunluk ayarlı ark tedavisi (VMAT) planlama yöntemleri karşılaștırıldı.

Yöntem: Meme koruyucu cerrahi ve aksiller lenf nodu diseksiyonu geçiren hastalar seçildi. Her hasta için ayrı ayrı 3D-CRT, IMRT ve VMAT planları yapıldı. Hedef hacimlerin ve risk altındaki organın (OAR) dozimetrik parametreleri karşılaştırıldı. Planlanan hedef hacim (PTV) olarak tüm memenin PTV'si ve lenfatik bölgenin PTV'si tanımlandı. Tüm hastalara 2 Gy/fraksiyonda toplam 50 Gy radyoterapi uygulandı.

Bulgular: Meme PTV'nin \%2'sinin aldığı doz IMRT planlamasında en düșüktü ( $p=0,001$ ), supraklaviküler bölge için ise VMAT'de en düșüktü ( $p=0,001)$. Aksilla bölgesi için PTV'nin \%95 ve \%98'i tarafından alınan doz en düșük 3D-CRT'de (sırasıyla; $p=0,002$ ve 0,045) bulundu. Kalp, ipsilateral ve kontralateral akciğer ve kontralateral meme için OAR dozları 3D-CRT planlamasında en düşüktü $(p<0,01)$. IMRT ise en düşük monitör birimlerini gösterdi ( $p=0,001)$.

Cite as: Özer EE, Soydemir GP, Kırlı M, Özkan G. Clinical Dosimetric Comparison of Three Radiotherapy Techniques for Left-Sided Breast and Lymphatic Irradiation. IKSSTD 2021;13(3):177-83

${ }^{\odot}$ Copyright 2021 by the İstanbul Kanuni Sultan Süleyman Training and Research Hospital / Medical Journal of Istanbul Kanuni Sultan Suleyman published by Galenos Publishing House.

๑Telif Hakkı 2021 İstanbul Kanuni Sultan Süleyman Eğitim ve Araștırma Hastanesi / Istanbul Kanuni Sultan Süleyman Tıp Dergisi, Galenos Yayınevi tarafından basılmıștr. 
Sonuç: Her üç planlama yöntemi de meme koruyucu cerrahi sonrası meme ve aksilla radyoterapi endikasyonları olan hastalarda dozimetrik kriterleri karșılar. Her tedavi tekniğinin kendi avantajları ve dezavantajları olmasına rağmen, 3D-CRT, uzun vadeli yan etkiler ve ikincil kanser gelişimi için önemli olan OAR'ler için daha düşük doz sağlayabilir.

Anahtar kelimeler: 3D konformal tedavi (3D-CRT), yoğunluk ayarlı radyoterapi (IMRT), hacimsel yoğunluk ayarlı ark tedavisi (VMAT), meme kanseri

\section{INTRODUCTION}

Globally, breast cancer is the most common cancer among women (1). The standard treatment for breast cancer is breast-conserving surgery or mastectomy with sentinel lymph node sampling. Based on the stages of the cancer, adjuvant chemotherapy, hormonotherapy, and radiotherapy (RT) are selected in the treatment process ${ }^{(2)}$.

Conventional two-dimensional (2D) treatments have been used as adjuvant breast radiotherapy (BT) following breast-conserving surgery. In 2D therapy, two tangential megavoltage photon beam fields are used for the breast, and depending on the depth, one or two opposed photon fields are used for the lymphatic field. Moreover, heterogeneous dose distributions are obtained with this complex method. It is impossible to obtain clear information about the doses to organs at risk (OAR) ${ }^{(3,4)}$.

Considering the long survival times for many breast cancer patients, modern treatment methods that will increase the quality of life of patients and reduce the possible longterm side effects have gained importance. In the last three decades, BT has become more complex. Since 1990, new treatment modalities, such as three-dimensional conformal radiotherapy (3D-CRT), intensity-adjusted radiotherapy (IMRT), volumetric modulated arc therapy (VMAT), and helical tomotherapy (HT), have been used for BT ${ }^{(5)}$.

In the 3D-CRT method, by using conventional tangential fields with wedges, the target volume dose homogenization would be achieved, and critical organ doses would be reduced in the treatment planning system (TPS). In the last 10-15 years, IMRT and VMAT treatment plans have been adopted in BT, and their utility have become increasingly widespread. Compared with conventional radiotherapy techniques, VMAT and IMRT can achieve highly conformal dose distributions with improved planned target volume (PTV) coverage while sparing normal tissues. VMAT also has the potential to offer additional advantages, such as reduced treatment delivery time compared with the conventional static field of IMRT ${ }^{(3-5)}$.

In this study, we compared the dosimetric differences between 3D-CRT, IMRT, and VMAT planning methods for the breast tangential field and lymphatic draining region following irradiation. We also evaluated the advantages and disadvantages of these treatment options in BT.

\section{METHOD}

\section{Patient Selection}

The simulation images and materials of a total of 10 patients who were treated for left-sided breast carcinoma in our clinic were used for this dosimetric study. All patients underwent breast-conserving surgery and axillary lymph node dissection. All patients were selected randomly.

\section{Patient Positioning and imaging}

Patients were placed in a supine position on the breast board. Their left arms were raised above their heads, which were turned to the opposite side. Around the nipple, the scar and incision lines were marked with a wire. Tomography images were taken from the larynx to the upper abdominal region. All computer tomography images were obtained using a slice with $0.5 \mathrm{~cm}$ thickness.

\section{TPS with Target Volumes and Critical Structures}

All the patients' planning tomography were reloaded in the system (Toshiba Aquilion). Irrespective of their indications, all clinical target volumes (CTV) for the whole breast, level 1 , 2,3, and supraclavicular (SC) lymphatic draining region were contoured according to the Radiation Therapy Oncology Group contouring atlas. PTV was formed by allowing a margin of $0.5 \mathrm{~cm}$ to the CTV in every direction by the same radiation oncologist using the TPS of Monaco 5.1 (Elekta AB PUBL, Stockholm, Sweden).

The heart, lungs, head of humerus, medulla spinalis, and contralateral breast were contoured as OAR. A total of 50Gy doses were administered to the PTV of the whole breast and the axillary and SC lymphatic region in 25 fractions.

The clinical constraints were:

- the lowest dose (D95\%) received by at least 95\% of PTV

- the maximum dose (Dmax) $110 \%$ of PTV and the minimum dose (Dmin) $95 \%$ of PTV 
- the percentage of volume receiving 20 Gy or more (V20Gy) $<30 \%$ for the ipsilateral lungs

- Dmax for the spinal cord for volume receiving $45 \mathrm{~Gy}$

- the mean dose (Dmean) for the heart < 5 Gy

- Dmean for the contralateral breast < 2 Gy

- Dmax for the contralateral lung and possible humerus head $\leq 45$ Gy

\section{D-CRT, IMRT, and VMAT Techniques}

3D-CRT, IMRT, and VMAT plans were done separately by the same medical physicist. The collapsed cone and Monte Carlo Algorithm was used for the IMRT and VMAT plans, respectively. 3D-CRT plans were created with the collapsed cone algorithm and 6-18 MV X-ray beams.

For 3D-CRT plans, SC-axillary and breast fields were planned as a single center using a half beam. Two opposed beams were used with 10- to 15-degree angles for the SC-axillary field. Areas were created by protecting the humerus head. Two tangential fields were created by preserving the lungs and heart and were used for PTV of the whole breast. Optimal plans were established by closing maximal dose zones in the small segments created below the fields (FIF). In the FIF segmental IMRT technique, the same beam orientation as that of 3D-CRT was used (Figure 1).

In the dynamic IMRT, the treatment plans were done using six fields with $6 \mathrm{MV} X$-rays. Field angles were selected according to the placement of critical organs. Figure 2 shows the IMRT plans of the breast and SC-axillary fields.

In the VMAT plans, two fields with 6 MV X-rays were used. Two arcs were used in the clockwise and counterclockwise directions. The arc geometry was chosen, considering the opposite breast. The start angles were chosen to spare contralateral OARs (like a tangential field). The finish angles were chosen to improve the dose on the $\mathrm{SC}$ region (Figures 3 ).

\section{Plan Comparison}

All plans were compared for the evaluation of dosimetric parameters. The treatment plans were compared using dose-volume histograms for the PTVs and OAR. Dose homogeneity was evaluated in terms of Dmin, Dmax, Dmean, $\mathrm{D} 95 \%$, D2\% (dose to $2 \%$ of the volume), and D98\% (dose to $98 \%$ of the volume).

For the OAR, the values of Dmean, V5, and V10 to the heart; $\mathrm{V} 5$ and $\mathrm{V} 20$ to the ipsilateral lungs and contralateral lungs; and Dmean to the contralateral breast were evaluated and compared ( $V x$ was defined as the percentage of a
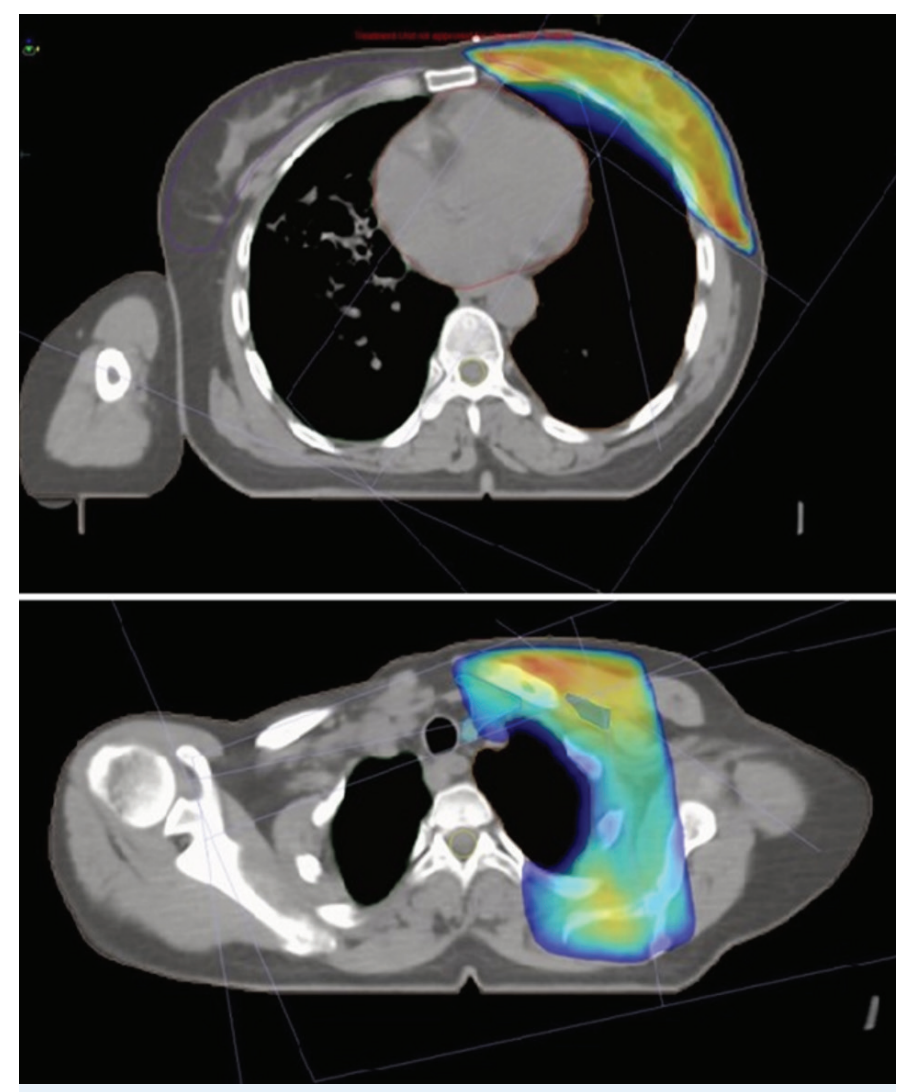

Figure 1. A plan of three dimensional conformal radiotherapy (3D-CRT) in an axial image of the breast, the supraclavicular and axillary fields

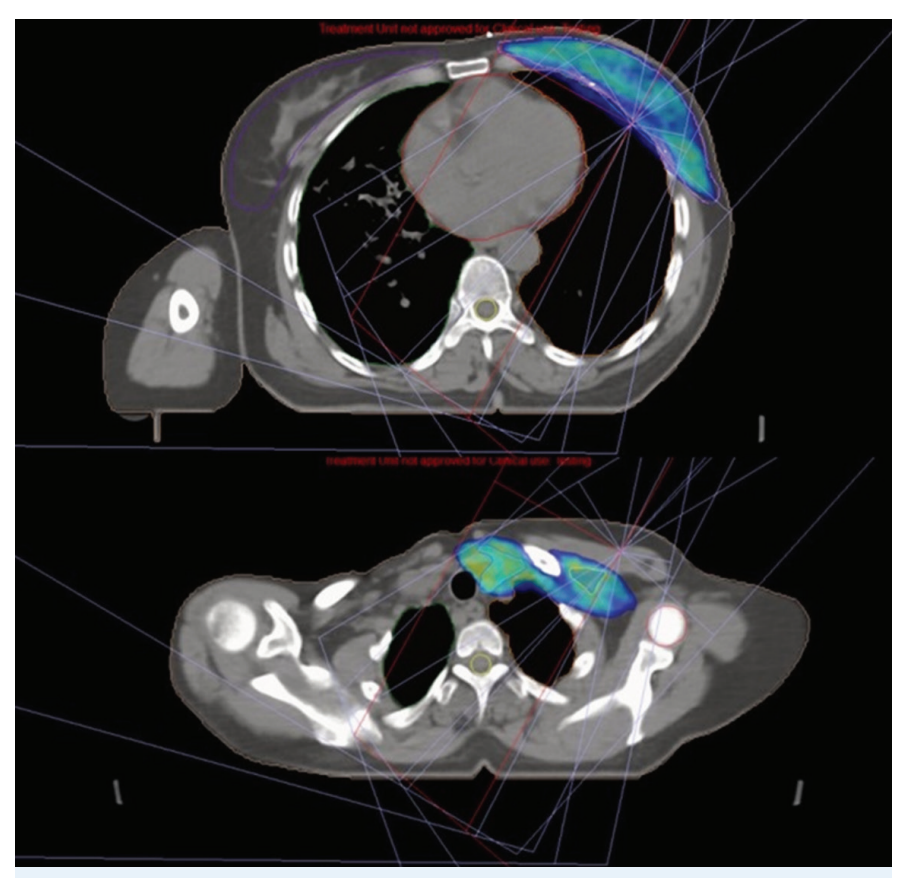

Figure 2. A plan of intensity-modulated radiotherapy (IMRT) in an axial image of the breast, the supraclavicular and axillary fields 

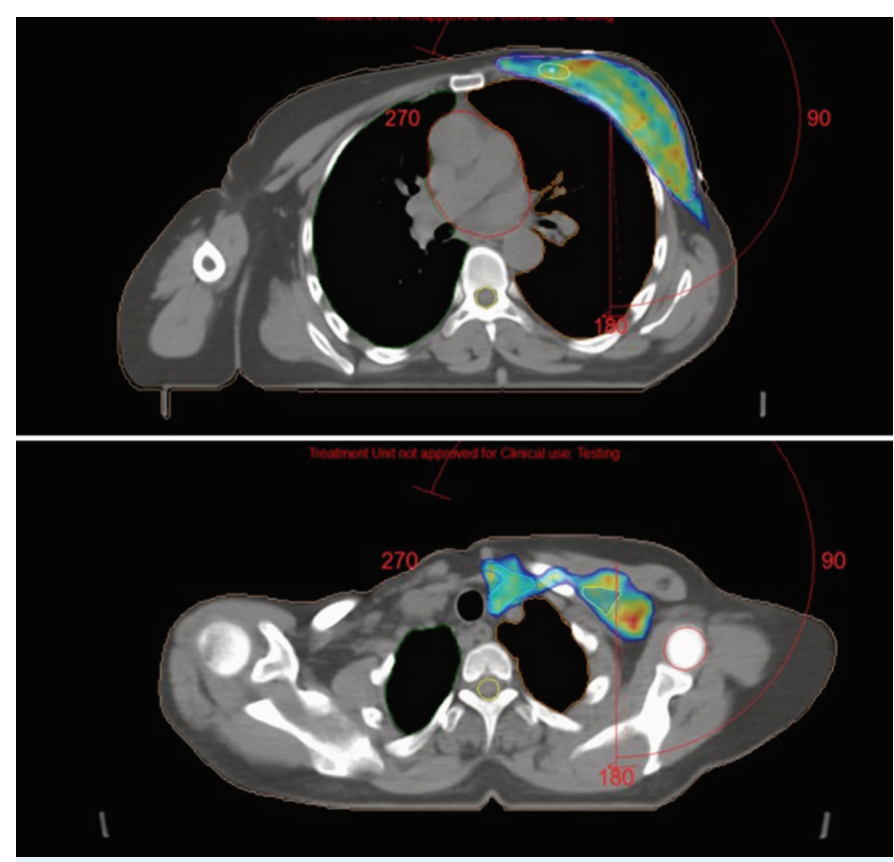

Figure 3. A plan for volumetric intensity-modulated arc therapy (VMAT) in an axial image of the breast, the supraclavicular and axillary fields

given tissue volume receiving at least x Gy). Moreover, all treatment plans were compared in terms of monitor units (MU).

\section{Ethics}

This study was conducted in accordance with the ethical principles of the Declaration of Helsinki, and a local committee approval for the human investigation was obtained. The study protocol was reviewed and approved by Clinical Research Ethics Committee (decision date: 24.04.2017; no: 2017/27). Informed written consent forms were read and signed by each patient before commencement of their treatment.

\section{Statistical Analysis}

All statistical analyses were done using NCSS (Number Cruncher Statistical System) 2007 program (Kaysville, Utah, USA). The difference between the descriptive statistical methods (mean, standard deviation, median, frequency, and minimum and maximum) was determined by Friedman test, and the difference between the 3D-CRT, IMRT, and VMAT methods was determined by the Bonferroni-corrected Wilcoxon signed rank test. Significance was adopted at $p<0.05$.

\section{RESULTS}

\section{Comparison of Target Volumes and Doses for IMRT, VMAT, and 3D-CRT}

There was no statistically significant difference between the IMRT, VMAT, and 3D-CRT techniques in terms of D95\% to the breast PTV of the subjects participating in the study ( $p>$ 0.05) (Table 1). There was a statistically significant difference between the three techniques in terms of D2\% to the SC PTV $(p=0.001 ; p<0.01)$. However, there was no difference among the techniques in terms of the D98\% to the breast PTV ( $p>$ 0.05).

No statistically significant difference was found between the three techniques in terms of D95\% and D98\% to the SC PTV ( $p>0.05)$. However, there was a statistically significant difference between the three techniques in terms of D2\% to the breast PTV ( $p=0.001 ; p<0.01$ ) (Table 1). A statistically significant difference was found among the three techniques in terms of D95\% and D98\% to the axilla PTV $(p=0.002$, $p<0.01 ; p=0.045, p<0.05$, respectively). There was no difference among the three techniques in terms of D2\% to the axilla PTV ( $p>0.05$ ) (Table 1 ).

\section{Comparison of OAR Doses and Parameters of the Three Different Techniques}

Differences in the OAR doses were also evaluated among the three different techniques. By comparing the techniques for heart doses, it was found that the mean dose, V5Gy and V10Gy in 3D-CRT, were significantly lower than those in the

Table 1. Comparison of dose-volume indices for planning target volumes between treatment planning techniques

\begin{tabular}{|l|l|l|l|l|}
\hline & IMRT & VMAT & 3DCRT & p \\
\hline PTV Breast & & & & \\
D95 (Gy) & 48.19 & 48.90 & 48.38 & 0.082 \\
D2 (Gy) & 50.76 & 51.73 & 53.97 & $0.001^{* *}$ \\
D98 (Gy) & 47.47 & 48.20 & 47.58 & 0.067 \\
\hline PTV SC & & & & \\
D95 (Gy) & 48.94 & 47.94 & 48.67 & 0.273 \\
D2 (Gy) & 51.82 & 51.58 & 53.65 & $0.001^{* *}$ \\
D98 (Gy) & 48.01 & 46.39 & 47.33 & 0.670 \\
\hline PTV Axilla & & & & \\
D95 (Gy) & 48.75 & 49.37 & 47.96 & $0.002 *$ \\
D2 (Gy) & 52.09 & 51.56 & 52.34 & 0.301 \\
D98 (Gy) & 47.77 & 48.70 & 46.79 & $0.045^{*}$ \\
\hline
\end{tabular}

Median values for all variables were noted; 3D-CRT: 3-dimensional radiotherapy, IMRT: Intensity-modulated radiotherapy, VMAT: VolumetricModulated arc therapy, PTV: Planning target volume, SC: Supraclavicular 
other techniques $(p<0.01)$. In terms of V20Gy on the left (ipsilateral) lung, VMAT was significantly the best technique $(p=0.001)$. The V5Gy of 3D-CRT was the lowest for both the ipsilateral lung and contralateral lung $(p=0.001)$. A statistically significant difference was found in terms of Dmean to the contralateral breast $(p=0.001)$, with 3D-CRT showing the lowest Dmean among the techniques $(p<0.05)$. Furthermore, there was a statistically significant difference between IMRT, VMAT, and 3D-CRT techniques in terms of Dmax to the humeral head $(p=0.001)$. Dmax to the humeral head in the IMRT technique was higher than that of VMAT and 3D-CRT techniques ( $p=0.001$ ). The best humeral head protection was provided by the VMAT technique. Finally, the Dmax to the medulla spinalis in the IMRT technique was significantly lower than that of the other techniques $(p=$ 0.005) (Table 2).

\section{Monitor Units}

As shown in Table 3, the 3D-CRT and IMRT techniques had significantly lower MUs than the VMAT technique $(p=0.001)$.

\section{DISCUSSION}

Post-lumpectomy adjuvant RT for the whole breast is the gold standard in breast cancer treatment. In the $21^{\text {st }}$ century, the traditional modalities used in RT for the whole breast and lymphatic regions have been replaced by modern

Table 2. Comparison of dose-volume indices for OAR between treatment planning techniques

\begin{tabular}{|l|l|l|l|l|}
\hline & IMRT & VMAT & 3D-CRT & p \\
\hline Heart & & & & \\
Dmean (Gy) & 4.97 & 4.64 & 3.38 & $0.002^{*}$ \\
V5 (\%) & 22.45 & 23.46 & 9.97 & $0.007^{*}$ \\
V10 (\%) & 10.86 & 5.81 & 5.18 & $0.001^{*}$ \\
\hline Ipsilateral Lung & & & & \\
V5 (\%) & 58.19 & 62,2 & 46.52 & $0.001^{*}$ \\
V20 (\%) & 24.48 & 14,82 & 23.97 & $0.001^{*}$ \\
\hline Contralateral Lung & & & & \\
V5 (\%) & 0.23 & 12.36 & 0 & $0.011^{*}$ \\
\hline Contralateral Breast & & & & \\
Dmean (Gy) & 1.4 & 2.02 & 0.86 & $0.001^{*}$ \\
\hline MS & & & & \\
Dmax (Gy) & 3.52 & 20.9 & 23.24 & $0.001^{*}$ \\
\hline
\end{tabular}

Median values for all variables were noted; 3D-CRT: 3-dimensional radiotherapy, IMRT: Intensity-modulated radiotherapy, VMAT: VolumetricModulated arc theraphy, PTV: Planning target volume; SC: Supraclavicular,V5: The percentage of the volume receiving 5 Gy or more (V5Gy), V20: The percentage of the volume receiving 20 Gy or more (V20Gy), Dmax: Maximum doses, Dmean: Mean doses, MS: Medullaspinalis treatment techniques. 3D-CRT with tangential fields is generally recommended for breast/chest wall and full lymphatic irradiation. The modern treatment modalities for breast cancer include IMRT, VMAT, and HT ${ }^{(3-7)}$. These modern techniques of BT each have their advantages and disadvantages. It has been demonstrated that these techniques are more successful in tumor control by administering a higher dose to the tumor site while allowing the better protection of critical organs.

However, the American Society of Radiation Oncology does not suggest the routine use of IMRT or VMAT in breast cancer irradiation, considering the potential risk of RTrelated malignancies and due to no significant clinical advantages ${ }^{(8,9)}$. To elucidate these controversial issues, we compared the dosimetric variables between the 3D-CRT, IMRT, and VMAT planning methods for the breast tangential field and lymphatic draining region following an irradiation and evaluated the advantages and disadvantages of these treatment options in BT. As a result, we found that the dose covering the PTV of the breast was lowest when IMRT was applied, whereas the dose covering the PTV of the axillar region was lowest when 3D-CRT was applied. The dose covering the PTV of the SC regions was lowest when VMAT was applied. Additionally, the mean dose to the contralateral breast was lowest when 3D-CRT was applied.

Most dosimetric comparison studies on RT techniques were done with the radiation on the whole breast and chest wall. In a study by Liu et al, the dosimetric differences between 3D-CRT, IMRT, and VMAT plans were compared for the left breast cancer. They found that the target of IMRT and VMAT plans have a better conformity; however, they found that the 3D-CRT plan had the lowest OAR doses ${ }^{(10)}$. Dogan et al. (11) also demonstrated that the IMRT technique could improve the dosimetry of the breast and regional nodes. They found that the use of IMRT improves the breast and regional node coverage while decreasing the doses to the lungs, heart, and contralateral breast when compared with 3D-CRT. However, 3D-CRT was demonstrated to be the best in terms of humeral head sparing (11). We also found that the lowest dose received by at least $2 \%, 95 \%$, and $98 \%$ of the

Table 3. Comparison of monitor units (MU) between treatment planning techniques

\begin{tabular}{|c|c|c|c|c|}
\hline & IMRT & VMAT & 3D-CRT & $p$ \\
\hline MU & 447.5 & 1071.2 & 477.5 & $0.001^{*}$ \\
\hline
\end{tabular}


PTV (especially D2\% PTV) and the lowest MUs was achieved by the IMRT planning of the left-sided breast. However, in contrast to the findings in literature, VMAT planning showed the lowest dose received by at least $2 \%$ of the PTV for the SC regions. The lowest dose received by at least 95\% of the PTV for the axillar region was detected in the 3D-CRT planning. Additionally, this planning showed the lowest doses for the OAR, including the heart, ipsilateral and contralateral lungs, and contralateral breast.

In a dosimetric study by Kivanc et al. ${ }^{(12)}$, 3D-CRT and four different IMRT techniques were used for a total of 10 left-sided breast cancer patients who had chest wall and axillary radiation. They found that the forward planned IMRT resulted in a significantly lower D95\% to the chest wall PTV compared to other techniques, as we found this lowest dose to the breast PTV in the IMRT planning. 3D-CRT provided significantly higher D2\%, Dmax, and Dmean to the chest wall CTV compared to the other techniques. They also found the lowest V5-V10 heart doses, contralateral lung doses, and contralateral breast doses in the forwardplanned IMRT ${ }^{(12)}$. Contrarily, we found the lowest mean doses and V5-V10 doses for OAR in 3D-CRT, except for the Dmax for the medulla spinalis, which was lowest in the IMRT planning.

Sirin et al. ${ }^{(13)}$ planned a total of 20 breast cancer patients with 3D-CRT and IMRT techniques for the chest wall, SC, axillary, and/or mammaria interna lymphatic regions and, in consistency with our findings, they found that IMRT was superior to 3D-CRT in terms of PTV. However, irradiated contralateral breast volume and V5 and V20 ipsilateral volumes were lesser in 3D-CRT, ${ }^{133)}$ as in our study.

A secondary cancer risk following BT is more crucial in the long-term survival (14-16). An increased risk of all secondary cancers following BT was reported as 1.22 relative risk in literature ${ }^{(17)}$. The increased secondary malignancy risk was associated with the increase of lower doses of radiation volumes and an increase in MUs and contralateral breast doses. The choice of the optimal treatment method must be performed in each patient individually, depending on the balance between all relevant risks ${ }^{(18-21)}$. IMRT may be superior to the other modalities due to lower doses to breast PTV and MUs, whereas 3D-CRT may be superior in terms of the lower risks on other organs.

\section{CONCLUSION}

All the planning methods met the dosimetric criteria in patients with breast and axilla radiotherapy indications after breast-conserving surgery. Although each treatment technique has its own advantages and disadvantages, 3D-conformal plans may provide a lower dose coverage for the OAR, which is important for long-term side effects and secondary cancer development.

\section{Ethics}

Ethics Committee Approval: The study protocol was reviewed and approved by Clinical Research Ethics Committee (decision date: 24.04.2017; no: 2017/27).

Informed Consent: Informed written consent forms were read and signed by each patient before commencement of their treatment.

Peer-review: Externally peer reviewed.

\section{Authorship Contributions}

Concept: E.E.Ö., G.P.S., M.K., G.Ö., Design: E.E.Ö., G.P.S., M.K., G.Ö., Data Collection or Processing: E.E.Ö., G.P.S., M.K., G.Ö., Analysis or Interpretation: E.E.Ö., G.P.S., M.K., G.Ö., Literature Search: E.E.Ö., G.P.S., M.K., G.Ö., Writing: E.E.Ö., G.P.S., M.K., G.Ö.

Conflict of Interest: No conflict of interest was declared by the authors.

Financial Disclosure: The authors declared that this study received no financial support.

\section{REFERENCES}

1. Ahmad A. Breast Cancer Statistics: Recent Trends. Adv Exp Med Biol. 2019;1152:1-7. doi: 10.1007/978-3-030-20301-6_1.

2. Krug D, Baumann R, Budach W, et al; Breast cancer expert panel of the German Society of Radiation Oncology (DEGRO). Current controversies in radiotherapy for breast cancer. Radiat Oncol. 2017;12:25. doi: 10.1186/ s13014-017-0766-3.

3. Zhang $F$, Wang $Y, X u$ W, et al. Dosimetric evaluation of different intensity-modulated radiotherapy techniques for breast cancer after conservative surgery. Technol Cancer Res Treat. 2015;14:515-523. doi: 10.1177/1533034614551873.

4. Lichter AS, Fraass BA, van de Geijn J, Padikal TN. A technique for field matching in primary breast irradiation. Int J Radiat Oncol Biol Phys. 1983;9:263-70. doi: 10.1016/0360-3016(83)90110-4.

5. Zhou GX, Xu SP, Dai XK, et al. Clinical dosimetric study of three radiotherapy techniques for postoperative breast cancer: Helical Tomotherapy, IMRT, and 3D-CRT. Technol Cancer Res Treat. 2011;10:1523. doi: 10.7785/tcrt.2012.500174.

6. Haciislamoglu E, Colak F, Canyilmaz E, et al. Dosimetric comparison of left-sided whole-breast irradiation with 3DCRT, forward-planned IMRT, inverse-planned IMRT, helical tomotherapy, and volumetric arc therapy. Phys Med. 2015;31:360-7. doi: 10.1016/j.ejmp.2015.02.005.

7. Supakalin $N$, Pesee $M$, Thamronganantasakul $K$, Promsensa $K_{t}$ Supaadirek C, Krusun S. Comparision of different radiotherapy planning techniques for breast cancer after breast conserving surgery. Asian Pac J Cancer Prev. 2018 Oct 26;19:2929-34. doi: 10.22034/ APJCP.2018.19.10.2929. 
8. Hickey BE, James $\mathrm{ML}$, Lehman $\mathrm{M}$, et al. Fraction size in radiation therapy for breast conservation in early breast cancer. Cochrane Database Syst Rev. 2016;7:CD003860. doi: 10.1002/14651858.CD003860.pub4.

9. Alongi F, Giaj-Levra N, Fiorentino A, et al. Low-dose bath with volumetric modulated arc therapy in breast cancer: "Much ado about nothing?". Tumori. 2016;102:335-6. doi: 10.5301/tj.5000516..

10. Liu H, Chen X, He Z, Li J. Evaluation of 3D-CRT, IMRT and VMAT radiotherapy plans for left breast cancer based on clinical dosimetric study. Comput Med Imaging Graph. 2016;54:1-5. doi: 10.1016/j. compmedimag.2016.10.001.

11. Dogan N, Cuttino L, Lloyd R, Bump EA, Arthur DW. Optimized dose coverage of regional lymph nodes in breast cancer: the role of intensitymodulated radiotherapy. Int J Radiat Oncol Biol Phys. 2007;68:1238-50. doi: 10.1016/j.jjrobp.2007.03.059.

12. Kivanc H, Gultekin M, Gurkaynak M, Ozyigit G, Yildiz F. Dosimetric comparison of three-dimensional conformal radiotherapy and intensity-modulated radiotherapy for left-sided chest wall and lymphatic irradiation. J Appl Clin Med Phys. 2019;20:36-44. doi: 10.1002/ acm2.12757.

13. Sirin BO, Kirecci O. Dosimetric Comparison of 3-Dimensional Conformal and Intensity-Modulated radiotherapy Planning Techniques in Breast Cancer. UHOD 2019; 29: 191-7.

14. Groarke JD, Nguyen PL, Nohria A, Ferrari R, Cheng S, Moslehi J. Cardiovascular complications of radiation therapy for thoracic malignancies: The role for non-invasive imaging for detection of cardiovascular disease. Eur Heart J. 2014;35:612-23. doi: 10.1093/ eurheartj/ehtll4.
15. Vasiljevic D, Arnold C, Neuman D, et al. Occurrence of pneumonitis following radiotherapy of breast cancer - A prospective study. Strahlenther Onkol. 2018;194:520-2. doi: 10.1007/s00066-017-1257-z.

16. Pierce SM, Recht $A$, Lingos $\mathrm{Tl}$, et al. Long-term radiation complications following conservative surgery (CS) and radiation therapy (RT) in patients with early stage breast cancer. Int J Radiat Oncol Biol Phys. 1992;23:915-23. doi: 10.1016/0360-3016(92)90895-0.

17. Zhang W, Becciolini A, Biggeri A, Pacini P, Muirhead CR. Second malignancies in breast cancer patients following radiotherapy: a study in Florence, Italy. Breast Cancer Res. 2011;13:R38. doi: 10.1186/bcr2860..

18. Lee B, Lee S, Sung J, Yoon M. Radiotherapy-induced secondary cancer risk for breast cancer: 3D conformal therapy versus IMRT versus VMAT. J Radiol Prot. 2014;34:325-31. doi: 10.1088/0952-4746/34/2/325.

19. Abo-Madyan Y, Aziz MH, Aly MM, et al. Second cancer risk after 3D-CRT, IMRT and VMAT for breast cancer. Radiother Oncol. 2014;110:471-6. doi: 10.1016/j.radonc.2013.12.002.

20. Hall EJ, Wuu CS. Radiation-induced second cancers: the impact of 3D-CRT and IMRT. Int J Radiat Oncol Biol Phys. 2003;56:83-8. doi: 10.1016/s0360-3016(03)00073-7.

21. Jin GH, Chen LX, Deng XW, Liu XW, Huang Y, Huang XB. A comparative dosimetric study for treating left-sided breast cancer for small breast size using five different radiotherapy techniques: conventional tangential field, filed-in-filed, tangential-IMRT, multi-beam IMRT and VMAT. Radiat Oncol. 2013;8:89. doi: 10.1186/1748-717X-8-89.8. 